\title{
Accounting-analytical model of innovation-active business entities
}

\author{
Anna Basova \\ Associate professor, department of finance and accounting \\ Irkutsk State Transport University \\ Irkutsk, Russian Federation \\ Ann168@mail.ru
}

\begin{abstract}
The necessity of improving the tools of indirect stimulation of the innovation-active business entities is substantiated. A review of the views of various authors on the problem of stimulating the activity of innovative business entities is presented. The necessity of the development of accounting and analytical support of the innovation-active business entities in order to generate relevant information on innovation processes for internal users is substantiated. The main stages of the author's method for adjusting tax rates within the regional taxation are presented. The factors influencing the innovation activity of the business entities are singled out. The definition "management accounting of innovations" is specified. The aims and the objectives of the management accounting of innovations are submitted. The objects of valuation in the management accounting of innovations are categorized. The stages of budgeting the innovative development are developed. The indicators of the budget of innovative development are formed. This model allows increasing the efficiency of the innovationactive business entities.
\end{abstract}

Keywords-innovations, innovation-active business entities, management accounting of innovations, budgeting, budget, innovation activity.

\section{EXISTING PROBLEMS OF TAX TOOLS TO STIMULATE INNOVATION ACTIVITIES}

The key priority of the country's development to implement the process of Russia's integration into the international economic space is innovation development of all spheres of social life. Innovative activity contributes to achieving the leading positions in the market. Significant financial resources are required to implement the priority tasks of the country. There are two distinct issues of concern: one relates to the searching for and selecting of the most accessible sources of financial support for the innovation activities and the other concerns the problems of accounting and disclosure information on innovative activities.

The high cost of innovations, slow payback of innovations, the uncertain economic situation in the country, the high interest rates on loans are the strongest negative factors hindering the innovative and investment activity of companies. In this connection, the development of tools of indirect stimulation of the innovation-active business entities is relevant. In addition, the development of approaches to reflecting innovation activity objects and the sources of their financing is becoming increasingly important.

L. V. Marabayeva, O. A. Sokolov, investigating the state regulation of scientific innovation activity in Russia, note that the influence of the government on the innovation processes can be expressed in the form of direct financial support to the innovation-active business entities or indirect methods (tax, customs and other benefits) [1]

I. S. Javadova also distinguishes direct and indirect methods of state innovation stimulation. The latter include tax and depreciation regulation, loans at reduced credit rates and government guarantees for loans, customs tariff regulation [2].

A. U. Bakhchisaray focuses on indirect methods of innovation activities stimulation. In his opinion, the indirect methods are directed to stimulate innovative processes, on the one hand, and to create favorable economic conditions and a socially-political climate for scientific and technical development, on the other [3]. Among these methods, the author includes the state investment guarantees, equipment amortization programs, measures to form and improve innovation infrastructure, venture financing, the weakening of rigid migration legislation, severe restrictions on the use of old technology and a tax credit.

The directions of the tax policy of the Russian Federation to implement the Strategy for the Development of Russia until 2020 underscore the importance of optimizing the existing system of tax benefits, as well as eliminating the available opportunities for tax evasion [4].

It becomes necessary to improve the tools of innovation processes tax stimulation with subsequent accounting and analytical support of innovation-active business entities to generate relevant information on innovation processes for internal users.

Tax incentives for the innovation-active business entities should be understood as a set of actions aimed at strengthening the interest of innovation-active business entities in the effective use of basic productive funds in the social useful and other encouraged activities, related to the development and implementation of new or improved products, technological processes and other types of 
innovative activity, due to the prospect of obtaining tax benefits as an instrument to stimulate innovation development.

Existing forms of tax incentives for innovative activities do not take into account how efficiently innovation-active business entities use the main production funds that affect the financial and property status of the enterprise as a whole, do not stimulate innovation activity by investing their own financial resources into their innovative development [5].

In order to stimulate innovation-active business entities, it is envisaged to expand the powers of the regions to establish a tax rate. In this regard, it is advisable to talk not about new tax benefits, but about the adjustment of the mechanism of taxation, taking into account the needs of innovative enterprises [6].

The author's method is based on the fact that the tax rates of regional taxes may be corrected by coefficient of the costeffectiveness. This coefficient characterizes the efficiency of the use of fixed assets (Fig. 1). The application of this method can help stimulate the innovative activity of enterprises located throughout the country, in contrast to existing benefits for businesses that are concentrated only on the territory of special economic zones. Author's method can be used in the activities of any enterprise that actively involves innovations in economic circulation [7].

1. Calculation of the annual amount of depreciation, as well as the residual and mid-annual balance of fixed assets of the innovation-active business entities

\section{$\downarrow$}

2. Calculation of property tax, transport tax, profit tax of the innovation-active business entities

\section{$\downarrow$}

3. Calculation of coefficients

- the coefficient of fin ancial return of the innovationactive business entities

- coefficient of profitability of turnover of the innovation-active business entities

4. Adjustment of tax rates of:

- property tax, transport tax, profit tax in the part of transfer to the regional budget by the coefficient of financial return

- the profit tax to be credited to the regional budget, the coefficient of profitability of turnover

\section{$\downarrow$}

5. Calculation of the sums of regional taxes taking into account the adjustment of the tax rates

\section{$\downarrow$}

6. Change in the tax burden of the innovation-active business entities

Fig. 1. Stages author's method of tax rate adjustment
The issue of providing accounting and analytical support for the innovation-active business entities becomes extremely important [8]. The main principle of the formation of information flows is the usefulness of data that are prepared for internal users in order to make effective management decisions [9]. Strengthening mutual influence and interdependence of various spheres and processes of the world economy, the complication of economic ties requires such system of accounting which would not be limited to the system of accounts, double entry, money meters and retrospective registration of events [10].

Innovations are characterized not only by the material form, but also by uniqueness and science intensity [11].

The creation of an appropriate system of management accounting can contribute innovation activities [12].

Management accounting of innovations can be viewed as a complex system for monitoring, collecting, recording, processing, systemizing information on factors that affect the innovative development of the business entity, the innovation potential of the enterprise as a whole, as well as individual structural divisions (responsibility centers). This system is designed to the planning, control, analysis of relevant information on costs for innovation activities and its financial results in a sufficient analytical section for the short-term and long-term solutions that stimulate innovation-active business entities.

Fig. 2 represents the main objectives of management accounting of innovations.

Among the factors, influencing the innovative potential of companies, let us distinguish the following (Fig. 3): stimulating innovation activity; hampering innovation activity; having a dual effect depending on their quantitative parameters (factors marked with an asterisk).

Along with the problem of searching the new mechanisms of tax incentives for the innovation activity, there is another problem, which is connected with the fact that domestic enterprises often ignore the introduction of a management accounting system. This is explained by the fact that the mechanisms for introducing achievements in scientific and technical progress, accounting the innovations of enterprises with different innovative strategies have not yet been fully developed.

Fig. 4 shows the objects of the management accounting of innovations. From the point of view of factors that have a direct and indirect financial assessment this classification enables the development of measures for management factors and allocate responsibility for the implementation of these measures.

Factors that have a direct financial evaluation are managed by a system of measures within a specific business process.

Factors that have an indirect financial assessment are managed with greater uncertainty. Actions to manage the factors are carried out within the framework of various economic processes, and these activities are not fully related to the impact on this factor. 


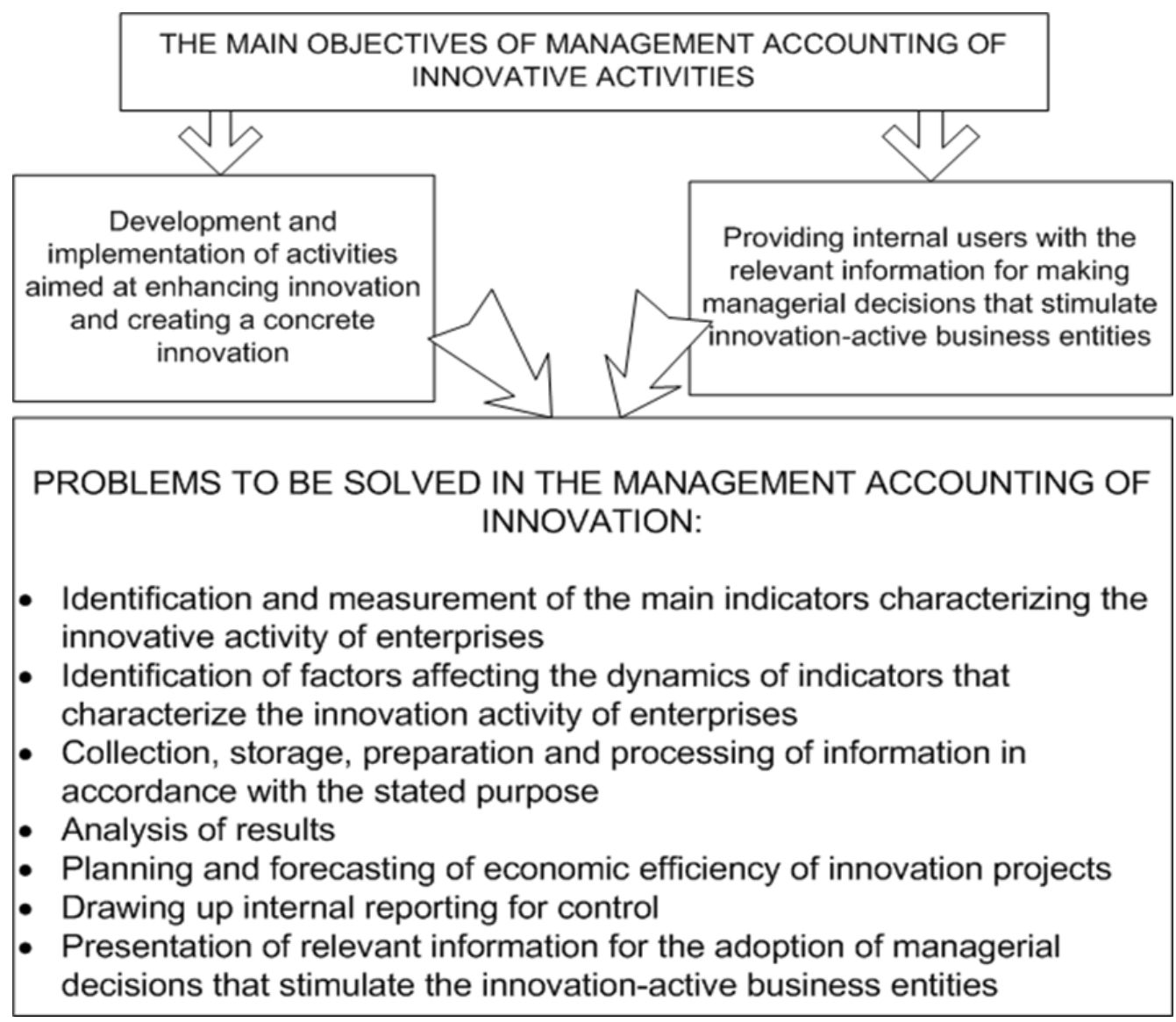

Fig. 2. The main objectives of management accounting innovation

\section{THE BUDGETING PROCESS OF INNOVATION ACTIVITIES}

The financial evaluation of the influence of income and expenditure factors fixes the achieved level of controllability of the factor and facilitates the effective management decisions. This assessment is provided by the budgeting process of innovation activity.

J.K. Shim and J.G. Siegel consider the budget as a quantitative plan of the enterprise's activities and program performance, which is a connected set of financial and (or) physical economic indicators of the company's activities [13]. In the authors' opinion, the identification of the concept of "budget" and "plan" contradicts the very purpose of the budgeting procedure.

Budgeting, integrating the processes of planning, control and analysis into a single system is a complex system that includes the following sections: the technology of planning the interrelated volume and cost indicators with the establishment of personal responsibility for their implementation, as well as the technology of financial management on the basis of determining the deviations from the established indicators [14].

As is known, the financial part of the general budget consists of the budget of capital investments, the budget of cash flows and the project of the balance of the enterprise [15].

In the authors' opinion, it is expedient to allocate a budget for innovation development in the budget for capital investments. This budget should contain the exhaustive information on all expenses considered above, from the point of view of factors having direct and indirect financial estimations. Fig. 5 shows the main stages of budgeting for innovative development.

The budget of innovative development of the enterprise should be formed, taking into account the data of the past periods and possible changes of conditions in the long term. Special attention should be paid to innovative projects that were initiated in previous periods and are promising, but for some reason not fulfilled in time.

Let us list the main economic indicators that can be included in the budget of innovative development (Fig. 6).

It is recommended to compile a consolidated budget of innovative development of the enterprise, which can be supplemented by functional budgets:

- the budget of repayment of financial liabilities (loans) for innovation activities;

- the tax budget. 


\section{Factors stimulating innovation activity}

\begin{tabular}{|c|c|}
\hline External environment & Internal environment \\
\hline $\begin{array}{l}\text { - Access to the world market of products (services) } \\
\text { - High world prices for products (services) * } \\
\text { - The presence of high technology abroad and the possibility } \\
\text { - Innovative climate at the federal and regional levels; } \\
\text { - Level of competition * } \\
\text { - The possibility of obtaining additional profit from the } \\
\text { introduction of innovations; }\end{array}$ & 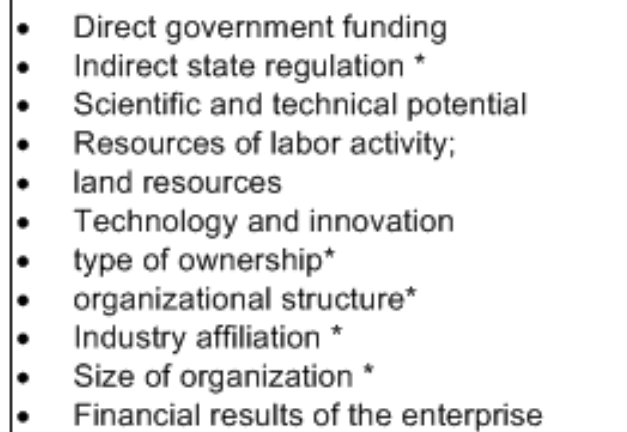 \\
\hline
\end{tabular}

\section{Factors hampering innovation activity}

\section{External environment}

- High competition in the world market of products (services)

- Food imports increase

- High customs duties, prohibitions on import of equipment

- The loss of purchasing power of the population

- Undeveloped market infrastructure

- Lack of protection of domestic producers from food imports

- Lack of effective mechanisms for indirect stimulation of innovation processes by tax instruments

\section{Internal environment}

- Lack of basic, negotiable and financial resources

- High depreciation of the material and technical base

- Imperfection of accounting and analytical support for the innovative-active business entities in order to obtain the relevant information on innovation processes, particularly on the reserves for innovative development, the volumes and sources of innovation financing, deviations from planned targets, financial results and directions of funds released by adjustments, into innovative development of enterprises

Fig. 3. Factors affecting the innovative activity of enterprises

The tax budget should incorporate the information on adjustments to tax rates in connection with the enterprise's achievement of the best performance indicators, using the method outlined earlier. In addition, it is recommended to include information on changes in the tax base and, as a consequence, tax payments to the regional tax budget, for which adjustments may be provided. The amount of released funds can be calculated as a result of a reduction in the tax burden, in the case of an increase in innovative activity, and, conversely, changes in the direction of increasing tax payments. Adjustments and calculated amounts should be described in detail, referring to the economic indicators of the previous period. Thus, the proposed aspects of accounting and analytical support for the innovation activity will contribute to the formation of reliable and relevant information on innovative processes taking place in companies. 


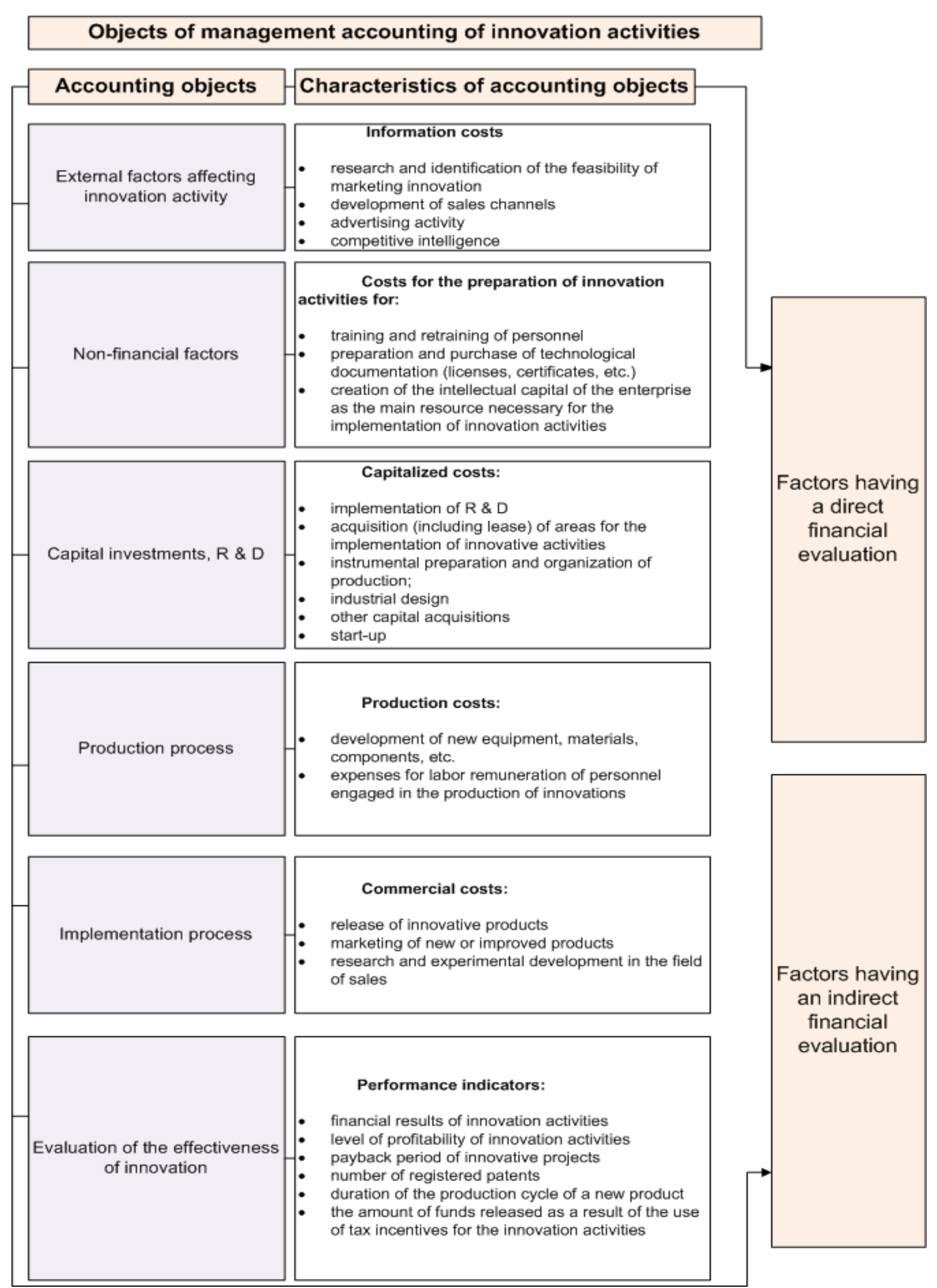

Fig. 4. Classification of valuation objects in the management accounting of innovations 


\section{The purpose of forming the innovative development budget and its main tasks are communicated to the persons responsible for drawing up the budget

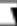 \\ 2. Identification of the factors constraining achievement of the set goals. Here it is appropriate to identify factors that have direct and indirect financial estimates \\ 1 \\ 3. Preparation of the program of the innovative development budget. It is advisable to divide the entire innovation project into stages and within each one to formulate goals, tasks, identify responsible persons and related activities \\ 4. Initial preparation of the innovative development budget. The preparation process should be directed from the bottom upwards, that is the budget is formed at the lowest level of management, further improved and coordinated at higher management levels

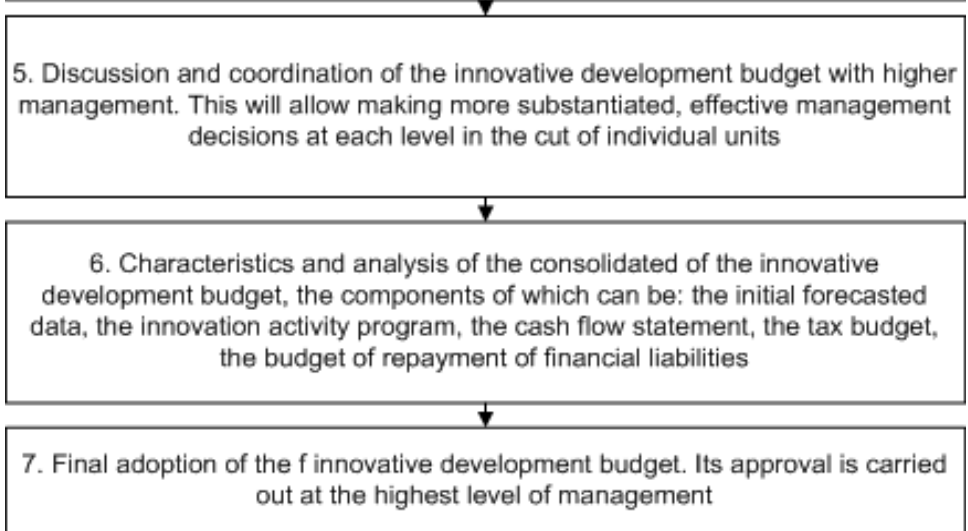

Fig. 5. Stages of budgeting the innovative development of an enterprise

\begin{tabular}{|c|c|}
\hline 1. Labor costs & $\begin{array}{l}\text { costs of salaries for specialists engaged in the development of an innovative project, } \\
\text { included payments to off-budget funds }\end{array}$ \\
\hline 2. Material costs & costs for the subjects of labor necessary for the innovation activities \\
\hline 3. Energy consumption & $\begin{array}{c}\text { costs for electricity and heat energy, water, steam, used to create an innovative } \\
\text { product (project) }\end{array}$ \\
\hline $\begin{array}{l}\text { 4. Property, equipment and } \\
\text { depreciation }\end{array}$ & $\begin{array}{l}\text { costs of purchasing means of labor, the current and capital repairs of existing } \\
\text { equipment and machines involved in creating an innovative product, renovation, } \\
\text { depreciation, etc. }\end{array}$ \\
\hline 5. Other expenses & Traveling, transportation costs \\
\hline
\end{tabular}

Fig. 6. Innovative development budget indicators

This will contribute to making prompt and most effective management decisions, aimed at achieving "positive" results of $\mathrm{R} \& \mathrm{D}$, to further expansion of the production of material goods and services through the introduction of scientific and technological progress in production.

The implementation of the proposed directions for increasing the efficiency of innovation activities will help to create a favorable investment climate in the process of modernization of the Russian economy.

\section{References}

[1] L.V. Marabaeva, O.A. Sokolov, "State regulation of science and innovation in Russia: trends and methods", Innovation, pp. 26-31, no 10.

[2] L.S. Dzhavadova "Financial incentives for innovation development in the system of state regulation", The author's abstract of the thesis of the candidate of economic sciences: Moscow, p.26, 2011.

[3] A.Ju. Bahchisaraj, "Indirect methods for stimulating innovation: international experience", Problems of developing foreign economic relations and attracting foreign investment: the regional dimension, no 1 , pp. 16-20, 2011 
[4] "The main directions of budgetary policy for 2015 and the planning period of 2016 and 2017', URL: http://www.minfin.ru/common/upload/library/2014/07/main/ONBP_201 5-2017.pdf

[5] Zachariadis M. "R\&D, innovation, and technological progress: a test of the Schumpeterian framework without scale effects", Canadian Journa of Economics, Canadian Economics Association, vol. 36 (02), pp. 566$586,2003$.

[6] N. I. Ivanova, Tax incentives for innovation processes, Moscow, p. 160, 2009

[7] A.V. Basova, A.S. Nechaev, "Taxation as a tool to stimulate innovation activities of active business entities", Modern research of social problems: electronic journal, no 6, 2012.

[8] V.V.Govdja, Zh.V. Degal'ceva, "Cost accounting, costing and budgeting in the sectors of agroindustrial complex", Krasnodar, p. 278, 2012 .

[9] G.P. Selivanova, N. A. Mezenin, N.V. Moskovskij, Management accounting, Ekaterinburg, p. 77, 2011.
[10] T. Arens, U. Ask, A. Barretta, The practice of management accounting: experience of European companie, Minsk, p. 416, 2004.

[11] J.A. Shumpeter, Theory of Economic Development (the study of business profits, capital, credit, interest and cycle conditions). Moscow, 453 p., 1982.

[12] N.A. Kovaleva, "Managerial accounting of innovations in scientific organization", Economic science and practice: materials of intern. sci. conf, Chita: Publishing House Young Scientist, p. 95-97, 2012.

[13] Dzh.K. Shim, Dzh.G. Sigel. Commercial Budgeting Basics. SaintPetersburg, p. 456, 2001.

[14] R.S. Kaplan, R. Cooper Cost and effect: using integrated systems to drive profitability and performance, Harvard Business School Press, 1998.

[15] T. Huynh, G. Gong, H. Huynh. "Integration of activity-based budgeting and activity-based Management, International Journal of Economics, Finance and Management Sciences”, no 1 (4), pp.181-18., 2013. 